\title{
First report of cucumber green mottle mosaic virus in Australia
}

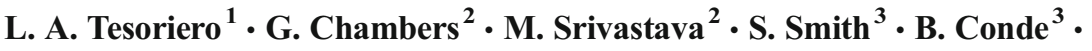 \\ L. T. T. Tran-Nguyen ${ }^{3}$
}

Received: 21 July 2015 / Accepted: 9 November 2015 / Published online: 3 December 2015

(C) Australasian Plant Pathology Society Inc. 2015

\begin{abstract}
Cucumber green mottle mosaic virus is reported for the first time from Australia. It was detected in watermelons (Citrullus lanatus) affected by a severe mosaic and stunted foliar development near Katherine in the Northern Territory. Tobamovirus morphology was initially detected in leaf sap by electron microscopy, and species identity confirmed by genetic tests.
\end{abstract}

Keywords Cucumbergreen mottle mosaic virus · Watermelon tobamovirus

Cucumber green mottle mosaic virus (CGMMV) is a member of the genus, Tobamovirus that causes serious losses of cucurbit crops worldwide. Australia was previously thought to be free of this virus despite its seed-borne etiology and the fact that virtually all commercial cucurbit seed is imported. The Northern Territory (NT) is an important production region for watermelon crops, supplying southern and some export markets primarily during the winter months. Production focused around Darwin and Katherine has been valued at over \$30-40 million in 2014 for watermelon and pumpkin crops (NT Farmers, pers. comm.). Previous surveys of cucurbit crops in

\section{A. Tesoriero}

len.tesoriero@dpi.nsw.gov.au

1 Central Coast Primary Industries Centre, New South Wales Department of Primary Industries, Ourimbah, NSW, Australia

2 New South Wales Department of Primary Industries, Elizabeth Macarthur Agricultural Institute, Menangle, NSW, Australia

3 Plant Industries, Northern Territory Department of Primary Industries and Fisheries, Darwin, NT, Australia these areas (Coutts and Jones 2005; Persley et al. 2011) confirmed the presence of several aphid-borne viruses, principally Zucchini yellow mosaic virus, Papaya ringspot virus and Cucumber mosaic virus, often occurring as multiple infections. CGMMV was not detected, although it was not specifically targeted using serological methods.

In July 2014 a survey of cucurbit crops was conducted on ten properties in the NT as part of a broader national survey for fungal and stramenopilous wilt and root rot pathogens. No formal survey methodology was used due to the vast areas planted and limited time. Instead, growers were interviewed and asked about plant health issues which were then investigated. Watermelon plants displaying typical mosaic symptoms on leaves were recorded on three farms in close proximity to one another near Katherine. Plants with strong foliar mosaic and mottle symptoms (Fig. 1) were observed in an immature crop on the third of these farms. A corridor of affected plants appeared to occur in the direction of the prevailing wind which was roughly perpendicular to beds. No aphids were observed, however some whiteflies were noted. Since no silver leaf whitefly borne virus diseases in cucurbits are known to occur in Australia, leaf samples were collected from a symptomatic plant on this farm and brought back to Sydney for laboratory analysis.

Initially, leaf sap was extracted in phosphate buffer and negative stain preparation made with $2 \%$ uranyl acetate on copper grids that were examined by transmission electron microscopy (Philips EM208). Typical rigid rod-shaped particles were observed (Fig. 2), consistent with a Tobamovirus.

Total RNA was extracted from symptomatic stem and leaf samples using PureLink® RNA Mini Kit (Ambion TM) 


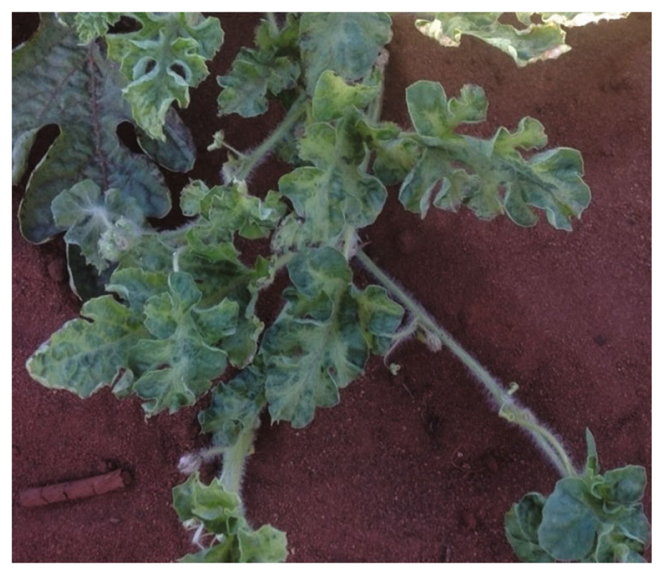

Fig. 1 Immature watermelon plant with Cucumber green mottle mosaic virus symptoms

according to the manufacturer's instructions. Conventional RT-PCR was performed using the primers 5'CATAGATGTCTCTAAGTAAGGTG-3' and 5' CCCTCGAAACTAAGCTTTCG-3' (Reingold et al. 2013). These primers amplify the CGMMV region flanking the coat protein and movement protein. A band consistent with the expected amplicon (1269 bp) was visualized on an agarose gel (Fig. 3). The purified DNA amplification product was directly sequenced in both directions at the Australian Genome Research Facility Ltd. with automated sequencing using an Applied Biosystems 3730xl capillary sequencer (www. agrf.org.au). Preliminary identification of the $1200 \mathrm{bp}$ sequence using a BLAST analysis revealed $99 \%$ homology to isolates of CGMMV described from cucumber (Cucumis sativum) in Canada (KP772568) and a bottle gourd (Lagenaria siceraria) from India (DQ767631) with 3-4 base

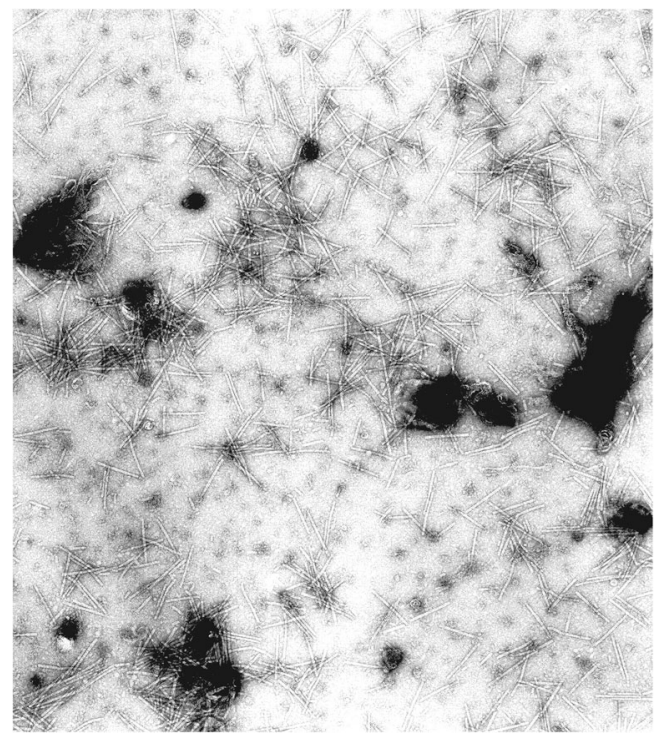

Fig. 2 Electron micrograph of negative stained sap preparation of Cucumber green mottle mosaic virus particles

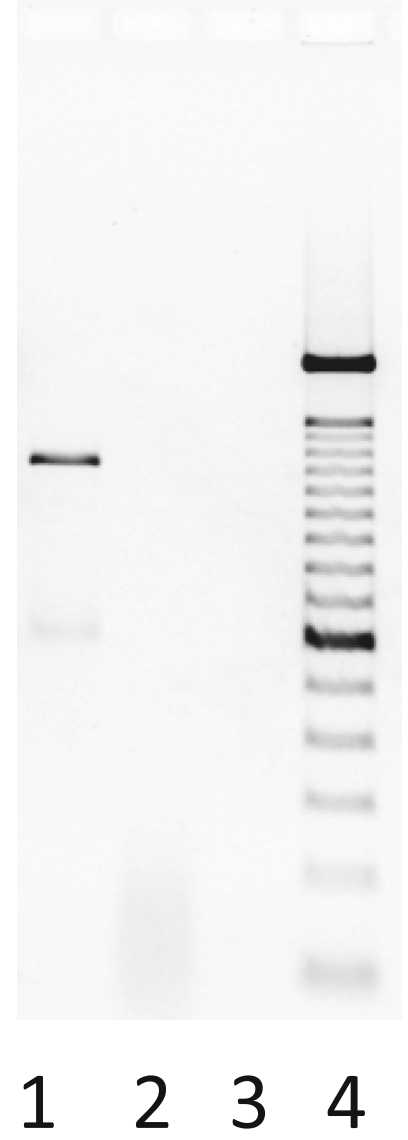

Fig. $31.5 \%$ Agarose gel with RT-PCR product (lane 1); healthy watermelon control (lane 2); water control (lane 3) and Invitrogen 100 bp DNA ladder (Life Technologies) (lane 4) using Cucumber green mottle mosaic virus specific primers (Reingold et al. 2013)

changes. Isolates from Europe shared lower levels of homology. For example, a recent report of an isolate from Israel (KF155231) was $95 \%$ homologous to the one described here (Reingold et al. 2013). CGMMV identification was confirmed in early September 2014 by an independent laboratory. The $1200 \mathrm{bp}$ nucleotide sequence was assigned the GenBank Accession number KM363234. It would appear that there has been recent spread of CGMMV around the world with recent reports of a similar strain from North America (Ling et al. 2014; Tian et al. 2014).

This is the first record of CGMMV in Australia. It is not known how long this virus has been present in Australia. Further targeted surveys and molecular diagnostics have confirmed the occurrence of CGMMV on several farms in the Katherine production area. Current studies, including whole genome sequencing of isolates, will determine if other strains of the virus have been introduced; a likely scenario given overseas experience such as in Israel (A. Dombrovsky pers. comm.) This study also highlights the value of transmission electron microscopy as a primary detection method when plant samples are infected with unknown or multiple virus infections. 
Acknowledgments Financial support from the Australian Government through ACIAR project HORT12/020 is gratefully acknowledged.

\section{References}

Coutts BA, Jones RA (2005) Incidence and distribution of viruses infecting cucurbit crops in the Northern Territory and Western Australia. Aust J Agric Res 56:847-858

Ling K-S, Li R, Zhang W (2014) First report of cucumber green mottle mosaic virus infecting greenhouse cucumber in Canada. Plant Dis 98:701
Persley D, Gambley C, Thomas J, Coutts B, Jones R, Wilson C, Tesoriero L, Forsyth L, Burfield T, Kay I (2011). Integrated viral disease management in vegetable crops. Final Report to Horticulture Australia Ltd Project VG07128, 160 pp.

Reingold V, Lachman O, Koren A, Dombrovsky A (2013) First report of cucumber green mottle mosaic virus (CGMMV) symptoms in watermelon used for rhe discrimination of non-marketable fruits in Israeli commercial fields. New Dis Reports 28:11

Tian T, Posis K, Maroon-Lango CJ, Mavrodieva V, Haymes S, Pitman TL, Falk W (2014) First report of cucumber green mottle mosaic virus on melon in the United States. Plant Dis 98:1163 